\title{
SELF-COMPACTING CONCRETE USE FOR CONSTRUCTION WORK ENVIRONMENT SUSTAINABILITY
}

\author{
Romuald Rwamamara ${ }^{1}$, Peter Simonsson ${ }^{2}$ \\ Division of Structural and Construction Engineering, Luleå University of Technology, \\ 97187 Luleå, Sweden \\ E-mails: ${ }^{1}$ Romuald.Rwamamara@ltu.se (corresponding author); ${ }^{2}$ Peter.Simonsson@ltu.se \\ Received 08 Sept. 2010; accepted 05 Aug. 2011
}

\begin{abstract}
Many of those working on construction sites are exposed to demanding work loads; construction workers lift and carry heavy materials and work in awkward postures. Occupational injuries and accidents due to poor ergonomics are more common in the construction industry and many times lead to human tragedies, disrupt construction processes and adversely affect the cost, productivity, and the reputation of the construction industry. In Sweden, it is reported that concrete workers have the highest relative work-related musculoskeletal injury frequency. Therefore, the use of ergonomic production methods to prevent this can have a significant human, social and financial impact. Research introduced here presents a case study of comparative analyses of ergonomic situations for concrete workers performing concrete casting processes. Three different ergonomic risk assessment methods were used to assess the physical strain, hand-arm vibration and noise affects risks involved in concrete casting work tasks. The combination of technical and managerial factors results in a system where workers are as efficient and safe as possible during their work tasks, and thus, makes the construction work environment sustainable.

The aim of our research is to find practical methods to evaluate and compare two different concrete casting methods from an ergonomic perspective. The focus is on the production of cast-in-place concrete bridge constructions where the traditional concrete casting method is compared with the SCC (Self-Compacting concrete) casting method. To be able to identify work-related musculoskeletal injury risks due to concrete casting work tasks, QEC (Quick Exposure Check for musculoskeletal risks), PLIBEL (Checklist for identification for Ergonomics Hazards) and ErgoSAM (Ergonomic production technology method) methods were used. Ergonomic risks analysis methods QEC, PLIBEL and ErgoSAM have all shown capabilities to evaluate construction work activities and thus determine whether a construction work activity constitutes a musculoskeletal risk to the worker or not before any ergonomic intervention is introduced.

As a result the present ergonomic risks emanating from work methods used in the traditional concrete placing can be significantly reduced with the use of self-compacting concrete (SCC) that eliminates awkward work postures, noise and hand arm vibration, thereby reducing if not eliminating musculoskeletal injuries among concrete workers during their concrete casting work tasks.
\end{abstract}

Keywords: sustainability, construction industry, concrete casting, concrete workers, ergonomic risk assessment, design and constructability.

\section{Introduction}

The construction industry is one of the most significant in terms of impact on the health and safety issues of their workers and according to Fung et al. (2008), the construction workers are at a higher risk of developing WMSDs (work-related musculoskeletal disorders) than workers in other industries. In Sweden, between 2008 and 2009, 450,000 people were employed in the construction industry. For many workers, their involvement in the industry leads to pain and suffering associated with different occupational injuries such as WMSDs which account for 65 per cent of all injuries among construction workers (Samuelsson 2008). Detecting injury risks of a construction site that could cause harm to workers is crucial for successful health and safety management, because a hazardous work environment affects not only workers health and safety but also the time and cost of the project (Kyo-Jin, Langford
2006). If the work environment is incorrectly estimated the workforce will be exposed to possible risks of work-related injuries which in the long run could slow down their operations undermining their productivity and increasing the possibility of unwanted accidents, thereby eventually increasing both time and costs for a specific project. Thus, promoting site health and safety is worth paying its financial costs rather than suffering from economical or production losses associated with a lack of health and safety, furthermore safety performance is perceived more and more as being an indicator of total operational efficiency in construction projects (Larcher, Sohail 1999; Fernández-Muñiz et al. 2009).

Health and safety problems in the form of workrelated illnesses and accidents cost money; which will ultimately be paid for by the client either directly or indirectly. Therefore, cutting the sector's high incidence of accidents and work-related illnesses could save for exam- 
ple the EU and its taxpayers up to 75 billion Euros (estimated to be about 8 percent of the total project costs) a year, claims the European Agency for Safety and Health at Work (2004).

Due to direct and indirect costs generated by an unhealthy construction work environment, both researchers and practitioners are constantly looking for better strategies and action plans to tackle health and safety issues in the production planning and construction processes. Through an adequate review of literature on the prevention of musculoskeletal disorders, Gervais (2003) stated that the integration of health and safety considerations into the planning of construction work, adoption of good management practices, provision of adequate training, improvement of working conditions, and elimination of biomechanical hazards was a satisfactory approach to prevent these injuries.

\subsection{Work-related musculoskeletal disorders (WMSDs) magnitude}

Pain, discomfort and loss of function in the back, neck and extremities are common among construction workers. These ailments are commonly termed Work-related Musculoskeletal Disorders (WMSDs). WMSDs are caused by or exacerbated by exposure to work related risk factors. They frequently lead to workplace absenteeism and early retirement. They are a prominent problem affecting workers in Europe. According to a European survey carried out in 2005, up to $25 \%$ of workers in the EU27 reported back pain, and $23 \%$ muscular pain related to work (European Agency for Safety and Health at Work 2010).

The Swedish construction work environment is regarded as the safest in the world (Flanagan et al. 2001) on the subject of physical health, working conditions, illnesses and accidents. Nevertheless, work environment related health problems are still to be tackled. Stress and other mental strains at work present the most dramatic development in recent years. However, the most common cause of work-related disorders in the recent fifteen years (from 1994 to 2009), has been the physical strain on the musculoskeletal system (Rwamamara 2007; Samuelson 2010). In the Swedish construction industry more than one man in five, twice as many as for all men employed, report work-related musculoskeletal disorders; this corresponds to 50,000 men (Lundholm et al. 2007). It is obvious that musculoskeletal illness is the construction industry's biggest problem $(71 \%$ of all reported work-related injuries in 2007), these injuries are caused by the ergonomic risk factors, where the most common risk factors are heavy lifting, strenuous work postures, repetitive operations and prolonged one-sided work (Samuelsson, Lundholm 2006; Samuelsson 2008). Different occupational groups in the Swedish construction industry are affected by work-related musculoskeletal disorders (WMSDs) at different frequency levels; however the highest relative frequency of reported WMSDs belongs to the concrete workers (Lundholm et al. 2007). The association between occupational risk factors, such as awkward postures, repetitive motions, heavy lifting, and WMSDs among concrete workers has been established by previous research (Hess et al. 2004; Goldsheyder et al. 2004). The cost to the worker of WMSDs is pain, along with loss of income through being unable to work.

\subsection{Construction work environment sustainability}

A sustainable development occurs when people's needs and welfare are taken into account without neglecting other aspects in the environment. In a sustainable society, the social, economic and environment related factors are dealt with in a manner that protects our environment. For the construction sector this entails the ability to produce buildings and infrastructure with less environmental impact as well as improving productivity and life quality. This further requires that sustainable development should not only be about the physical environment but also about people and their interaction (Halliday 2008).

The objective of construction work environment sustainability is derived from the concept sustainable safety and health in construction which was introduced by Sathyanarayanan Rajendran and John Gambatese at Oregon University in USA. Current sustainable, or "green", design and construction practices are according to the researchers primarily aimed at minimizing environmental and resource impacts and improving the safety, health, and productivity of a building's final occupants. Designing and constructing buildings using current sustainability practices may, or may not, benefit construction worker safety and health. However, if a building is to truly be labelled sustainable, its design and construction must address worker safety and health during all lifecycle phases, including the construction phase (Gambatese, Rajendran 2006).

\section{Research objective}

Considerable research has been carried out to evaluate WMSDs in the construction industry and to identify intervention requirements to reduce risk levels. However, little research has been carried out that focuses on the individual trades within the industry. This is particularly true for the concrete casting trade. The research objective of the work reported in this paper is a two-fold objective. The objective is to determine the impact of the work methods employed for concrete casting in bridge construction in Sweden that impose WMSD risks to concrete workers and further recommend a working method that is conducive to a sustainable work environment for concrete workers. Hierarchical task analysis (HTA) was used to describe and analyze concrete tasks. In this study, two different concrete casting methods (i.e. traditional vibrated concrete and the selfcompacting concrete (SCC) were compared and concrete casting tasks were assessed for occupational exposure to hand transmitted vibration (HTV) and noise, as well as for WMSD risk using the Quick Exposure Check (QEC), PLIBEL checklist and ErgoSAM method.

\section{State of the art literature review}

\subsection{Concrete casting work methods}

Concrete mixes that are easy to handle and place have most always been preferred by practitioners, and to achieve this 
with traditional vibrated concrete (TVC) it has been customary to increase the level of consistence to make the mix more flow-able (e.g., De Schutter et al. 2008). For compaction of the TVC and to de-aerate and hence create the strength of the concrete, poker vibrators and other types of vibrators are used. These vibrators produce high noise levels and when working with these tools, the work is often carried out in unhealthy postures, (Fig. 1 a-d below) resulting in a number of workers carrying around and using heavy equipment compacting the concrete. On the contrary, most often projects are under staffed due to a lack of qualified workers. This somewhat negative balance generally results in a poor working environment, unnecessary stress during different working operations, lower productivity, and a more expensive production when compared to other parts of the construction industry and other lines of work e.g. manufacturing industry.

According to a study at Danish Technological University, DTU (Nielsen 2006) 10\% of a concrete worker's average day consists of concrete casting activities e.g. pouring, vibrating and curing the concrete, thus working in stressful working postures and being exposed to back pains.

As an alternative to traditional vibrated concrete, Self Compacting Concrete (SCC) has been introduced. SCC is a concrete where no additional inner or outer vibration is necessary for the compaction, as the concrete compacts itself alone due to its self-weight when flowing

a)
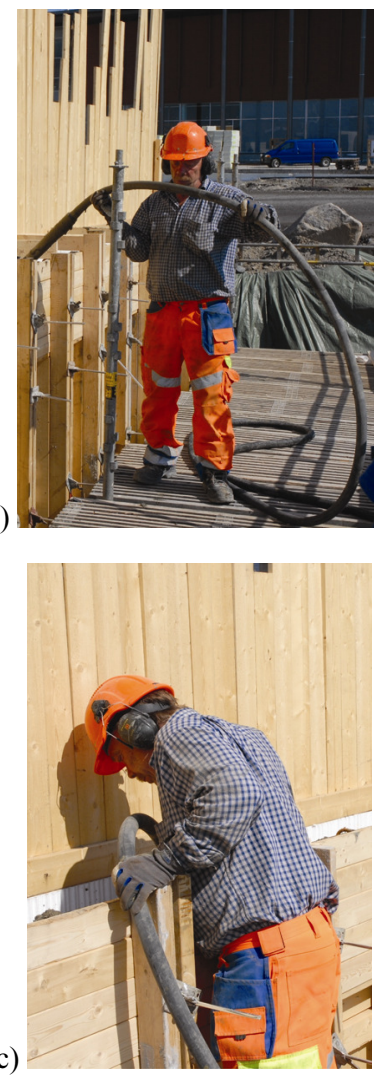

b)

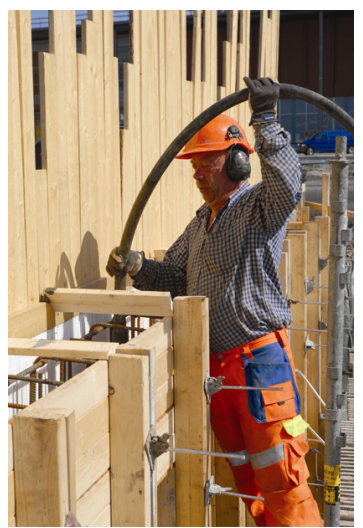

d)

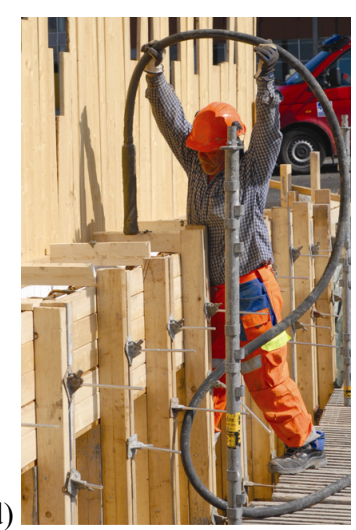

Fig. 1. Work postures when compacting traditional concrete in wall structure: a) Lifting the poker vibrator to the formwork; b) Lowering and/or raising it into/up from the formwork; c) Checking if concrete is vibrated enough; d) Lifting the poker vibrator to the next spot for vibration

in the formwork. For the success of SCC, it is crucial to define the performance of the product, which can, according to the Growth project Testing-SCC, be differentiated into three main parameters: 1) Filling ability; 2) Passing ability and 3) Segregation proneness (Emborg et al. 2005). For these parameters, criteria should be established to be met by a proper mix design depending on the geometry of the structure to be cast, reinforcement, form type and, method and local tradition on how to pour the concrete (Fig. 2a and b). In structural members with a high percentage of reinforcement it also easily fills all form voids and steel gaps.

a)

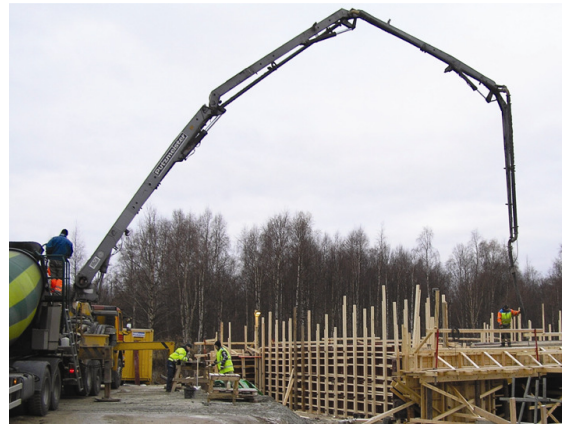

b)

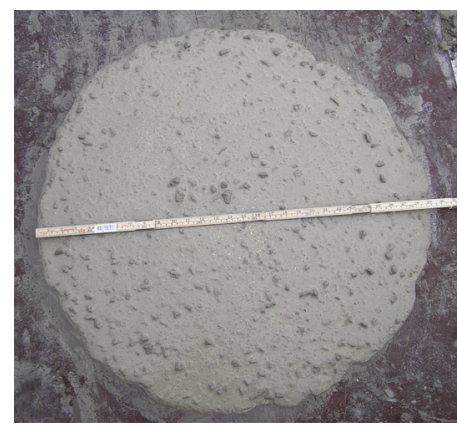

Fig. 2. SCC being pumped into formwork (a); Slumpflow test on SCC measuring approximately $740 \mathrm{~mm}$ (b)

In general SCC offers many advantages for cast-inplace construction as well as for the precast and prestressed concrete industry. In regard to the working environment the following are worth mentioning, less noiselevel problems at construction sites, i.e. easier communication, eliminated problems associated with heavy vibrating equipment, improved quality and durability results in less rectification work and reduced concrete volumes due to higher strength (Cussigh 2007; Emborg et al. 2007). According to recent international findings, SCC is on the cutting edge of scientific and technological developments (Shah et al. 2007; Cussigh 2007).

\subsection{Early design for safety and buildability}

The intention of design is to produce a structure which is buildable, durable, maintainable and aesthetically pleasing (Ray 1996). It is therefore important for designers to also bear in mind workers' safety both during construction and maintenance when designing a project. Hence, designers influence the ergonomic environment directly through concept and detailed design; designers also choose structural frame and materials to be used and 
hence influence the logistics and the way materials are handled at the construction site. Unfortunately, many designers and planners have the need for more knowledge of construction sites to understand how their decisions will influence the work being carried out at site (Jergeas, Van der Put 2001).

To be able to utilize new ideas and to improve e.g. productivity and/or safety such as is the case with SCC, the design phase needs to be in focus.

De Schutter et al. (2008) claim that in order to be able to obtain maximum benefit from SCC, it is important to adopt the technique as early as possible during design, thus making it possible for this technology to be adopted and used during the construction process. Consequently, the design decisions affect how a building or a bridge is to be built and determine the types as well as level of resources to be involved in the conversion process (Wong et al. 2004).

Adams (1989), listed 16 parameters affecting buildability. One of them is "Design for safe construction", in which he concludes that the design must be arranged so that working with materials and components and wherever traversing for access on a constructions site is essential, it can all be performed in a safe manner. A commonly accepted definition of Buildability is "the extent to which the design of a building facilitates ease of construction" (Ray 1996), i.e. buildability is about how the design can make the construction phase more efficient, productive and safe according to Adams (1989) and Ray (1996).

Furthermore, to be able to achieve good productivity at a production site, the workers need to feel safe in their work environment. The design stage is thus important for the health and safety of workers, the productivity at a construction site and the amount of waste produced at a house or a bridge project.

\subsection{Economy of health and safety}

There are direct and indirect costs for a company associated with workers' sick leaves. Direct costs are such personal costs seen in companies' bookkeeping/accounting, examples of such are, sick leave pay, social fees, vacation salary, and insurance fees. Indirect costs are such costs that are not related to workers e.g. production loss costs, loss of quality costs.

During the $1920 \mathrm{~s}$, according to Rose and Orrenius (2006), Heinrich (Heinrich 1931) performed studies on accidents within companies; he suggested that a company's indirect costs were four times higher than the direct costs. Rose (2001) calculated the indirect costs caused by work related personal injuries i.e. accidents and diseases to be 19 times the direct costs for companies within the construction industry. According to the European Agency for Safety and Health at Work (2010) the indirect costs for WMSDs lies between 10 to 30 times higher than the direct costs. In this report they found that the estimated costs for WMSDs is per person affected each year between $6800 €$ and $11200 €$, this cost comes from high absence rates and productivity losses. The absenteeism due to workers being sick affects the productivity by about $7 \%$, according to this study, for instance, one can say that the timetable for each project is delayed by about $7 \%$.
According to the Swedish Social Insurance Agency (2004) injury cost estimations, the single biggest cause for sick leaves is back pain which accounts for $15 \%$ of all sick leaves among men and $12 \%$ of sick leaves among women. The average of the total back pain illness compensation per case for men (focusing on men which constitutes $92 \%$ of the construction industry's workforce) is approximately $4600 €$, this cost denotes $45 €$ per sick leave day. Back pain is the most common illness among men, accounting for $17 \%$ of all sickness compensations. Considering only the construction industry, Samuelsson and Lundholm (2006) reported that out of all 1582 cases of sick leaves caused by occupational illnesses reported in the year 2004, some 1342 of them were caused by ergonomic risk factors (including vibration and noise).

Furthermore, 279 cases of WMSDs were reported among concrete workers in Sweden (Lundholm, Swartz 2006), their sick leave compensations could approximately cost up to 1.3 million $€$ for the Swedish taxpayers. This number should be evaluated in contrast to the consumption of ready mix concrete (RMC) which in Sweden is roughly 3 million $\mathrm{m}^{3}$ per year. If these numbers are extrapolated into figures related to the EU, the cost would end up as 214 million $€$ for the European taxpayers, since the total consumption of RMC in the EU is approximately 491.5 million $\mathrm{m}^{3}$ per year. There are of course other direct and indirect costs such as productivity loss and hiring substitute workers that are often not calculated.

\section{Assessment tools and methods}

\subsection{Interviews and observations}

Along with interviews with concrete workers, observations were performed in the form of site-walkthroughs. Moreover, the work situation was filmed with a video recorder and the film was analysed after the construction sites visits. The analysis of concrete casting work situations was carried out on the computer at the office, whereby the ambiguous parts could be repeated and experienced concrete workers could be consulted.

The filming was done on three bridge construction sites where traditional concrete casting and the SCC casting were used. Traditional concrete casting (Fig. 3a) produces substantial noise levels and vibrating tools are used for concrete compaction; whereas the SCC casting (see Fig. 3b) uses a self-compactable concrete. SCC compacts itself under its own weight and is de-aerated almost completely while flowing in the formwork without the need for the labour intensive vibration usually associated with concrete placing.

\subsection{Risk analysis methods}

Using the data from interviews with workers, observations of the workers placing concrete as well as the video films of the work situations; three ergonomic risk analysis methods, the ergonomic checklists QEC, PLIBEL as well as ErgoSAM were used to assess the level of musculoskeletal risk exposure in the two different concrete casting work methods. 

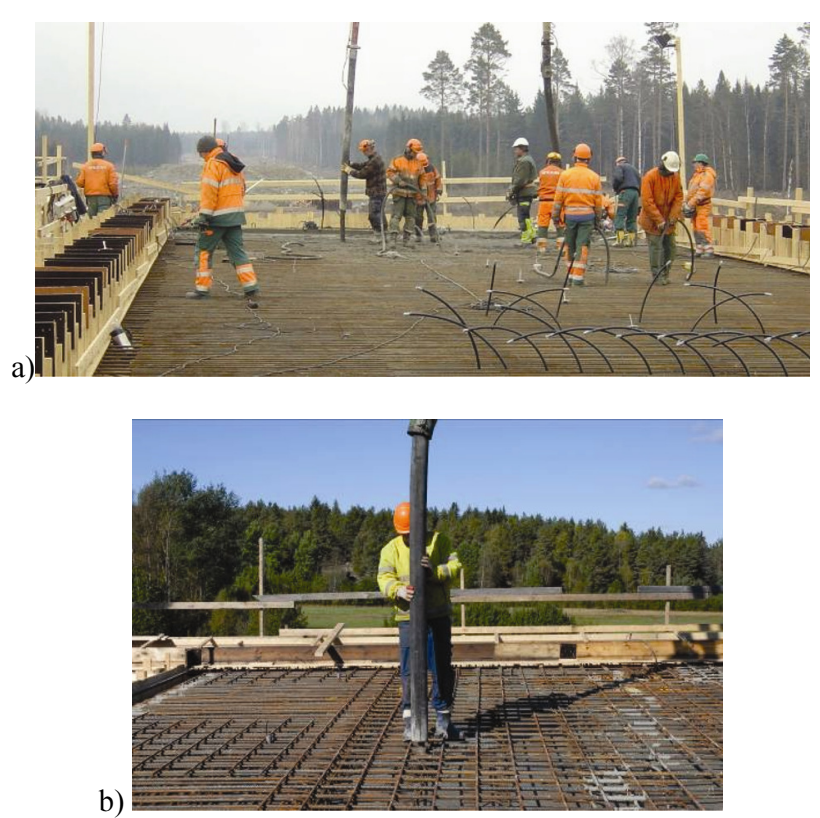

Fig. 3. Typical work situation during traditional concrete casting (a); Typical work situation during SCC concrete placing (b)

The Quick Exposure Check (QEC) was developed at Robens Centre of Health Ergonomics, University of Surrey, UK (Li, Buckle 1997, 1999). The method is used to assess exposure to WMSD risk factors for the back, shoulder/arm, wrist/hand, and neck. Both the observer and the worker collect data. The observer completes a checklist on the worker's postures' and repetitive movements with respect to four body areas: back, shoulder/arm, wrist/hand and neck. In the worker's case, a checklist is used to record information about the task duration, maximum weight wrist, hand force exertion, vibration, and visual demands of the task. Body area scores are calculated by combining the data from both checklists and comparing the result to values in the QEC assessment tables. Action Level scores are calculated for each body area using Equation (1), developed by Brown and Li (2003):

$$
\mathrm{QEC} \% \text { Score }=\left(\mathrm{E} / \mathrm{E}^{\max }\right) * 100
$$

where: $\mathrm{E}$ - body area exposure score; $\mathrm{E}^{\max }$ - maximum potential body area exposure score.

The best possible score that can be obtained for each body area is $0 \%$, while the worst possible score is $100 \%$. A score below $40 \%$ is deemed to be acceptable and no work related intervention is required. Scores above $40 \%$ indicate that the body area in question is at risk of developing WMSDs and requires intervention to reduce the risk. The Action Levels for QEC are presented in Table 1 (Brown, Li 2003). Fundamentally, the greater the score the greater the WMSD risk for each body area.

Assessments can take place in real time while the workers carry out their tasks, or by recording postures using video or photographs for later analysis off-site. QEC is comprehensive, quick, user friendly and simple to use. The method is found to have good sensitivity and usability (David et al. 2008) and it is applicable to a wide range of tasks such as manual handling, repetitive tasks, and static or dynamic work (Li, Buckle 1997, 1999).
Table 1. Action Levels for QEC

\begin{tabular}{c|l|c}
\hline Action Level & \multicolumn{1}{|c}{$\begin{array}{c}\text { Intervention } \\
\text { Recommended }\end{array}$} & QEC\% Score \\
\hline $\begin{array}{c}\text { 1: Acceptable } \\
\text { risk }\end{array}$ & Acceptable posture & $<40 \%$ \\
\hline $\begin{array}{c}\text { 2: Moderate } \\
\text { risk }\end{array}$ & $\begin{array}{l}\text { Further investigation } \\
\text { needed; changes may be } \\
\text { required }\end{array}$ & $40-49 \%$ \\
\hline $\begin{array}{l}\text { 3: High risk } \\
\text { 4: Very high } \\
\text { risk }\end{array}$ & $\begin{array}{l}\text { Investigation and changes } \\
\text { needed soon }\end{array}$ & $\begin{array}{l}\text { Investigation and changes } \\
\text { required immediately }\end{array}$ \\
\hline
\end{tabular}

The PLIBEL method (Kemmlert 1995, 2006) is a checklist method that links questions concerning awkward work postures, work movements, and design of tools and the workplace to specific body regions. In addition, any stressful environmental or organizational conditions should be noted. In general, the PLIBEL method was designed as a standardized and practical assessment tool for the evaluation of ergonomic conditions in the workplace.

Furthermore, another analysis method, ErgoSAM was used to evaluate the risk for musculoskeletal injuries, ErgoSAM is a production technology method designed for use by SAM-authorized engineers with a certain level of proficiency in load ergonomics. The method is based on Sequence-Based Activity and Method Analysis (SAM) and has been expanded with the addition of information about working area (zone) and weight of objects handled (Amprazis et al. 2002).

\subsection{Comments on risk assessment methods}

QEC and PLIBEL as methods for musculoskeletal risks identification are both easy to use and quick to execute while assessing a working environment such as a construction site. QEC focuses its risk assessment on four upper body regions and PLIBEL assesses risks for the same body parts in addition to the lower body regions, thus serving as an adequate complement to the QEC method.

Although both QEC and PLIBEL methods make it possible for the most important risk factors for WMSDs to be assessed, in the case of concrete casting, hand-arm vibration risks are not referred to specifically, instead both methods look at the vibration risk in general. Both QEC and PLIBEL checklists are simple to use and are not time consuming. Most importantly, these two risk assessment methods facilitate a partnership between the practitioner and the worker to make the assessment of musculoskeletal risks. Thereby encouraging participative ergonomics to bring about solutions or ergonomic interventions that are based on worker consultation and worker's partial evaluation of his/her work environment problem. For example, David et al. (2008) highlight that QEC is of value in prompting improvements and in evaluating the benefits (reduction in exposure to WMSD risk factors) by providing a structured process to help prioritize the need for change in working methods. It can form a basis for communication between management, production engineers 
and designers when evaluating interventions and allocating resources to fund improvements (David 2005).

\subsection{Noise}

Noise is generally emitted as a by-product of the processes in construction and other industrial settings. Construction work involves many work situations where noise might be harmful to construction workers' hearing. The Council of European Communities (2003) in its directive 2003/10/EC lays down the minimum health and safety requirements to protect workers from the risks of noise exposure. The basic parameters of environmental noise are: 1 - intensity or sound pressure level; 2 - frequency content; 3 - variation with time. The sound pressure level is expressed on a logarithmic scale in units of decibels (dB).

The sensitivity of human hearing varies with frequency. A frequency weighting filter, the A-weighting filter, is commonly used when measuring environmental noise to provide a single number level descriptor that correlates with human subjective response. Sound pressure levels measured using the A-weighted filter are notated as $\mathrm{dB}(\mathrm{A})$.

The A-weighted sound pressure level is widely accepted by acousticians as a proper unit for describing environmental noise (Drugă et al. 2007). The daily and weekly noise exposure levels $\left(\mathrm{L}_{\mathrm{EX}, 8 \mathrm{~h}}\right)$ are the timeweighted average of the A-weighted sound pressure levels for a nominal eight-hour working day or a nominal week of five eight-hour working days as defined by international standard ISO 1999:1990 (EC 2003).

According to the Swedish Work Environment Authority (2005), limit values of the noise exposure level for workers are established, Table 2 . There are different limit values depending on whether the worker is using hearing protection or not. The lower limit of $\mathrm{L}_{\mathrm{EX}, 8 \mathrm{~h}} 80 \mathrm{~dB}(\mathrm{~A})$ implies that no action is needed. When the value increases and is in between $80-85 \mathrm{~dB}(\mathrm{~A})$ the worker needs to use hearing protection. When the exposure level increases over $85 \mathrm{~dB}(\mathrm{~A})$ specific action needs to be taken. This can include information and education, a specific plan of action, regular hearing checks and using other technical solutions. Using SCC, a different technical solution, the compacting work is eliminated and therefore the sound associated with the vibrating moment is eliminated (Shah et al. 2007).

Table 2. Limit values for noise exposure levels according to the Swedish Work Environment Authority (AFS 2005)

\begin{tabular}{|c|c|c|c|c|}
\hline & $\begin{array}{l}\text { Lower } \\
\text { limit }\end{array}$ & $\begin{array}{l}\text { Upper } \\
\text { limit }\end{array}$ & & $\begin{array}{l}\text { Limit } \\
\text { value }\end{array}$ \\
\hline $\begin{array}{l}\text { Daily noise } \\
\text { exposure level } \\
\mathrm{L}_{\mathrm{EX}, 8 \mathrm{~h}}(\mathrm{~dB})\end{array}$ & 80 & 85 & $\begin{array}{l}\text { Daily noise } \\
\text { exposure level } \\
\mathrm{L}_{\mathrm{EX}, 8 \mathrm{~h}}(\mathrm{~dB})\end{array}$ & 85 \\
\hline $\begin{array}{l}\text { Maimum } \\
\text { A-adjusted } \\
\text { value } L_{\text {pA F max }} \\
\text { (dB) }\end{array}$ & - & 115 & $\begin{array}{l}\text { Maimum } \\
\text { A-adjusted } \\
\text { value } L_{\mathrm{pA} \text { F max }} \\
\text { (dB) }\end{array}$ & 115 \\
\hline $\begin{array}{l}\text { Impulse value } \\
\mathrm{L}_{\text {peak }}(\mathrm{dB})\end{array}$ & \multicolumn{2}{|c|}{135} & $\begin{array}{l}\text { Impulse value } \\
L_{\text {peak }}(d B)\end{array}$ & 135 \\
\hline
\end{tabular}

\section{Results and discussion}

Measurements from castings of two similar superstructures with approximately similar amount of reinforcement were used for the evaluation of the PLIBEL and QEC checklists respectively. The first project was cast using self compacting concrete and the other one was cast with traditional vibrated concrete. When it comes to the vertical castings, ErgoSAM and QEC checklist were used for the evaluation. Two different plate structures with about the same measurements (height and width) were studied during casting also using self compacting concrete in the first and traditionally vibrated concrete in the second project.

\subsection{PLIBEL checklist results}

The PLIBEL checklist for concrete workers task of casting the traditional concrete reports a moderate percentage (38.1\%) for risk factors present for the lower back, and low percentage $(36.4 \%)$ of risk factors present for the neck, shoulder, upper back, elbow, forearm and hands (Table 3). For the worker's SCC casting task, the PLIBEL checklist reports a low percentage (between 23 and $25 \%$ ) of risk factors present for the feet, knees, hip and low back. Table 4 shows that both methods of concrete casting share several environmental and organizational modifying factors with one exception regarding the hand-arm vibration risks which are particular to the compacting of traditional concrete casting. Two similar bridge construction projects are compared in Table 3 . The results in Table 3 give the score of potential body regions for musculoskeletal injury risks. The score for environmental and organization risk factors are used to modify the interpretation of musculoskeletal scores.

Table 3. PLIBEL score for musculoskeletal risk factors scores for slab concrete casting work tasks

\begin{tabular}{|c|c|c|c|c|c|}
\hline \multicolumn{6}{|c|}{ Musculoskeletal Risk Factors Scores } \\
\hline & 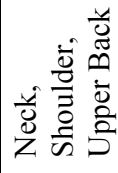 & 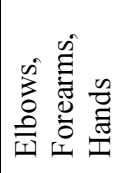 & $\begin{array}{l}\overrightarrow{0} \\
0 \\
.1\end{array}$ & 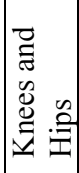 & $\begin{array}{l}\frac{y}{0} \\
\tilde{E} \\
3 \\
0 \\
\end{array}$ \\
\hline $\begin{array}{l}\text { SUM (Conventional } \\
\text { concrete casting) }\end{array}$ & 9 & 4 & 2 & 2 & 8 \\
\hline SUM (SCC casting) & 4 & 1 & 2 & 2 & 5 \\
\hline $\begin{array}{l}\text { Percentage (Conven- } \\
\text { tional concrete casting) }\end{array}$ & 34.6 & 36.4 & 25 & 25 & 38.1 \\
\hline $\begin{array}{l}\text { Percentage } \\
\text { (SCC casting) }\end{array}$ & 15 & 9 & 25 & 25 & 23.8 \\
\hline
\end{tabular}

Table 4. PLIBEL results for environmental and organizational factors slab concrete casting work tasks

\begin{tabular}{l|c}
\hline \multicolumn{2}{c}{ Environmental / Organizational Risk Factors Score } \\
\hline SUM (Conventional concrete casting) & 7 \\
\hline SUM (SCC casting) & 6 \\
\hline Percentage (Conventional concrete casting) & 70 \\
\hline Percentage (SCC casting) & 60 \\
\hline
\end{tabular}


The PLIBEL checklist for the concrete worker at wall concrete casting tasks (Tables 5 and 6) while using traditional concrete, reports a moderate percentage (between 37 and $50 \%$ ) of risk factors present for the neck, shoulder, upper back, and lower back. Whereas the concrete worker was casting the SCC, PLIBEL checklist reported much lower percentage (between 8 and 25\%) which means that by using SCC there is less likelihood of injury risks to these body regions.

Table 5. PLIBEL score for musculoskeletal risk factors for wall concrete casting work tasks

\begin{tabular}{|c|c|c|c|c|c|}
\hline \multicolumn{6}{|c|}{ Musculoskeletal Risk Factors Scores } \\
\hline & 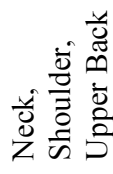 & 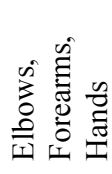 & 岕 & 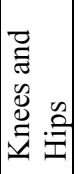 & $\begin{array}{l}\frac{y}{0} \\
\tilde{E} \\
0 \\
0 \\
0\end{array}$ \\
\hline $\begin{array}{l}\text { SUM (Conventional } \\
\text { concrete casting) }\end{array}$ & 10 & 5 & 3 & 3 & 8 \\
\hline SUM (SCC casting) & 2 & 1 & 2 & 2 & 3 \\
\hline $\begin{array}{l}\text { Percentage (Conven- } \\
\text { tional concrete casting) }\end{array}$ & 40 & 50 & 37.5 & 37.5 & 40 \\
\hline $\begin{array}{l}\text { Percentage } \\
\text { (SCC casting) }\end{array}$ & 8 & 10 & 25 & 25 & 15 \\
\hline
\end{tabular}

Table 6. PLIBEL results for environmental and organizational factors for wall concrete casting work tasks

\begin{tabular}{l|c}
\hline \multicolumn{2}{c}{ Environmental / Organizational Risk Factors Score } \\
\hline SUM (Conventional concrete casting) & 5 \\
\hline SUM (SCC casting) & 3 \\
\hline Percentage (Conventional concrete casting) & 50 \\
\hline Percentage (SCC casting) & 30 \\
\hline
\end{tabular}

According to Table 6, several environmental and organizational modifying factors are present as well in both two types of concrete casting, even though these modifying factors are higher in the traditional concrete casting than in SCC casting.

\subsection{Heirarchical Task Analysis and QEC Checklist results}

The Hierarchical Task Analysis (HTA) was used to highlight elements of concrete casting tasks that expose concrete workers to WMSD risk factors as part of their normal working day, specifically; sustaining awkward postures, working at above shoulder height and frequent lifting of vibrating electric or pneumatic pokers.

\subsubsection{WMSD risk factors for body areas assessed}

Back: The concrete workers' backs were in almost neutral posture when casting SCC both vertically (wall casting) and horizontally (floor casting), However when the workers' backs were slightly flexed when performing the concrete casting of the floor using TVC.

Shoulder/arm: The majority of work was carried out between shoulder and hips level when concrete casting a wall, and below chest and hips height when concrete casting the floor. The concrete worker's shoulders and arms were frequently moving in all tasks except when SCC was used.

Wrist/hand: Concrete workers adopted postures which involved frequent and repetitive flexion and extension of the wrist/hand. This was particularly prevalent when casting TVC in walls where the concrete poker needs to be frequently lifted and lowered from one spot to another.

Neck: When performing concrete casting the walls using TVC, concrete workers' necks were sometimes in an extended posture. In contrast, their necks were occasionally flexed when working with SCC.

\subsubsection{The quick Exposure Check (QEC)}

The mean QEC scores obtained for the body areas for the seven tasks are presented in Fig. 4. All the body areas were found to be at significant of developing WMSD's during all tasks done in concrete casting using TVC, in particular when doing vibrating concrete in the walls. Except for the concrete casting using SCC on the floor, all other cases have generated Mean QEC scores that were greater than $40 \%$. This is equated to Action Levels 2, 3 and 4 which indicated moderate, high and very high WMSD risks respectively (see Table 1 ). The interventions recommended for each Action Level are presented in Table 1.

In accordance with the QEC \% exposure scores obtained in Fig. 2, it shows that in the studied case study all conventional concrete casting work tasks have high levels of exposure for the back especially when using the concrete vibrator. These high levels of exposure should be reduced.

The average exposure scores are high for the shoulder/arm body area, and the exposure levels are very high when using the concrete poker. Performing the concrete casting tasks on a horizontal plane (floor) or vertical plane (wall) seems to have the same effect on the shoul$\mathrm{der} / \mathrm{arm}$, except when the concrete vibrator is used, when it is indicated that the exposure levels were slightly

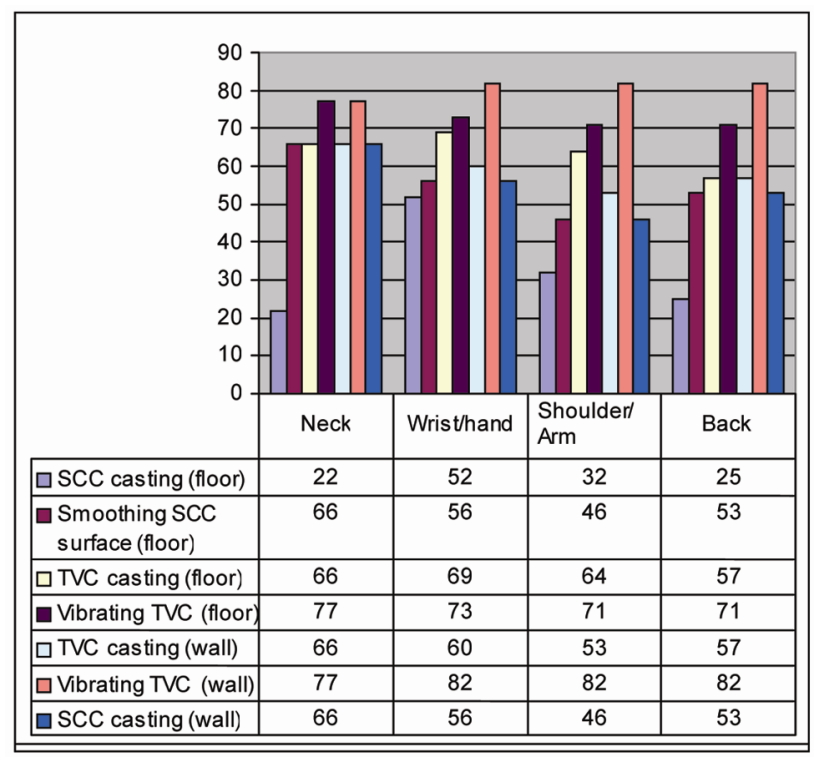

Fig. 4. QEC \% scores for concrete casting tasks 
reduced when vibrating the concrete on the floor in comparison to vibrating the concrete in the wall.

Fig. 4 also shows that the high exposure scores in wrists and hand during the conventional concrete casting especially when the concrete poker is used. There is still no major distinctive difference between the exposure levels during concrete casting on the floor or on the wall. Furthermore, Fig. 4 indicates that all work tasks have high exposure levels for the neck except for the work task of smoothing SCC surface. These high exposure levels are explained by the time factor ( 4 to 8 hours workday) which does not change for the concrete worker.

It was also observed and further confirmed by the concrete workers answers related their work organization and environment that other work-related health risks (such as vibration, work pace, stress and driving at work) do occur due to the environmental and organizational factors that are present in both concrete casting methods, with the exception of the vibration risk factor, in which case hand-arm vibration only affects the workers while casting the conventional concrete which requires a compacting process. Risk to musculoskeletal injury due to the work pace adopted during SCC concrete casting was quasi absent; however for the conventional concrete casting, QEC results reported moderate exposure levels. This is explained by the fact that the concrete worker has to vibrate the conventional concrete as soon as it is cast and before the concrete settles.

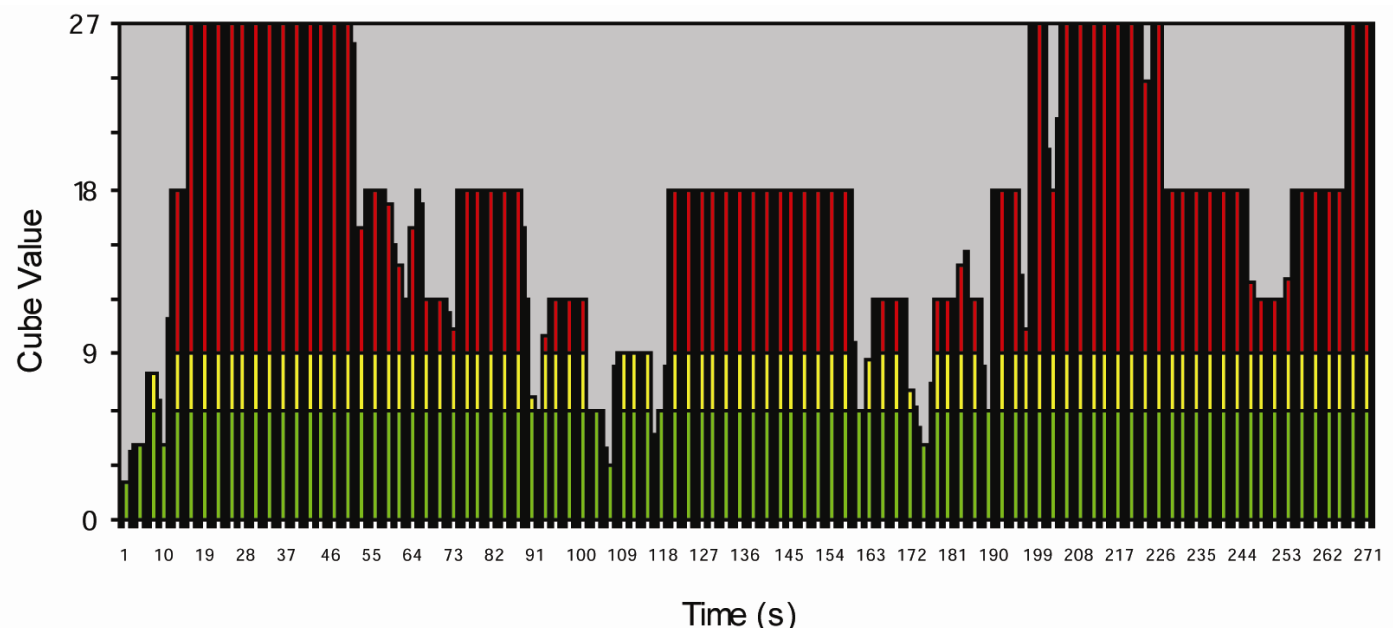

Fig. 5. ErgoSAM analysis of a short work cycle of a concrete worker working with TVC (traditional Vibrated Concrete). Measured cube mean value $=18.2$. A cube value under 6 is acceptable, 6 to under 9 is conditionally acceptable and 9 and above is unacceptable

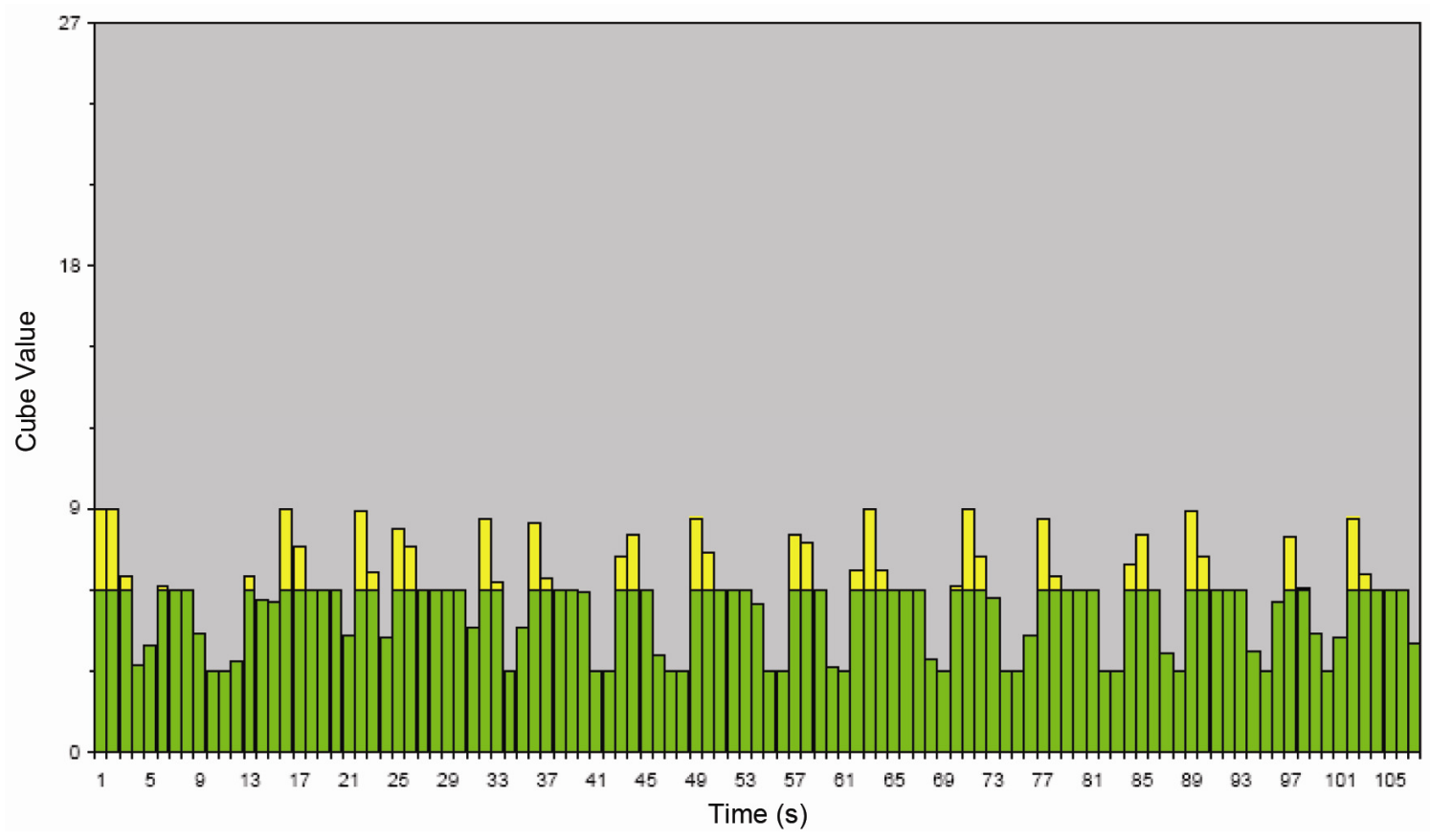

Fig. 6. ErgoSAM analysis of concrete worker's short work cycle during SCC casting. Measured cube mean value = 5.7. A cube value under 6 is acceptable, 6 to under 9 is conditionally acceptable and 9 and above is unacceptable 


\subsection{Ergonomic analysis, ErgoSAM results}

After observing concrete workers performing their jobs on the construction site, and after informal interviews with concrete workers, the classic work cycles for different methods of concrete casting became obvious. Based on this information, video films were taken and analyses of representative short work cycles were performed to identify any risks for WMSDs for concrete workers performing their tasks using different construction methods namely conventional and industrialised methods. Results of the analyses for representative work cycles are presented in Fig. 6, where different loads on concrete workers are represented by Cube values.]

The Cube value or the load level falls within three levels; where under 6 is acceptable, 6 to under 9 is conditionally acceptable and 9 and above is unacceptable. For example, the work cycle mean value of 18.2 obtained in ErgoSAM analysis in Fig. 5 falls into the unacceptable area. Here the concrete workers are casting a relatively small plate structure, only about 3 metres high. During casting they are constantly lifting the heavy poker vibrators in awkward working positions and repositioning the vibrators into the concrete (see Fig. 1 a-d above) resulting in an unacceptable working environment according to the ErgoSAM model.

The above discussed results of TVC should be compared to the findings in Fig. 6, when a similar plate structure was cast with SCC. The work cycle mean value of 5.7 was obtained in the ErgoSAM analysis in the case of SCC casting, thus making these work tasks acceptable as far as the worker's work-related musculoskeletal health is concerned, and hence entails no risk factors for WMSDs. Consequently, it becomes obvious that the normal concrete casting work exposed the worker to WMSD risk factors, over three times higher than working with SCC casting.

\section{Conclusions}

Employees who are well and content with their work are a key factor in a successful company. It is vital for the company to ensure that the working environment and conditions provide the right setting for employees to achieve peak performance in their work. Apart from the personal discomfort involved, work-related problems and ill-health cost money in the form of impaired quality, productivity losses, and increased employee turnover and sick leave. Occupational safety costs will ultimately be paid for by the client either directly or indirectly.

In this study, the comparison between traditional vibrated concrete (TVC) and Self Compacting Concrete (SCC) has indicated that SCC impact of working conditions (physical strain, hand-arm vibrations and noise) is very important in terms of concrete workers' musculoskeletal health as the SCC casting eliminates hand-arm vibration and reduces strenuous physical work which are usually an integral part of the traditional concrete casting i.e. musculoskeletal disorders.

The casting of TVC and SCC were analyzed using three exposure assessment methods; PLIBEL, QEC and
ErgoSAM. The high amount of effort required to vibrate the TVC between the steel reinforcement structures is a risk factor associated with this process as compared to SCC. The models gave the following results:

- PLIBEL: Using SCC instead of TVC shows a risk reduction of five times for neck, shoulders, upper back, elbows forearms and hands. For feet, knees, hips and lower back the reduction is $50 \%$ to roughly $70 \%$;

- QEC: Comparing TVC and SCC when casting a wall gives the following results, Neck same score, Wrist/hand SCC results in a moderate and TVC results a high score, Shoulder/arm and Back TVC results in a very high score and SCC results in a moderate score (according to Fig. 4);

- ErgoSAM: Results in a three times improvement if SCC is used instead of TVC when casting a wall. The value of 18.2 (Fig. 5) for TVC is well in the unacceptable area and should be avoided immediately.

Possible interventions include using steel fibres mixed in the TVC or using SCC in order to eliminate the pulling and pushing of concrete vibrators through narrow steel reinforcement cages.

Considering for instance a case with a 10 metre high plate structure with dense reinforcement, the improvement of working environment is possibly even larger. This is due to the fact that the worker has to climb down inside the construction carrying the vibrating equipment to be able to compact the concrete sufficiently. This results in an exceptionally poor working environment, and also in a probable loss of productivity, due to much lower unit time for casting traditional vibrated concrete.

Practically SCC can be useful to shorten the construction time of large-scale construction, but it could also be used in various projects to eliminate vibration and noise risks, thus improving the working environment on the site (Okamura, Ouchi 2003; Brite Euram 2000). However, the most common use of SCC is probably when there is a narrow section to be cast, where the proper concrete vibration could be hindered, as an example of this, casting against roofs in tunnels so called tunnel linings can be mentioned.

The concrete worker often bends at the waist to force the vibrator through the reinforcement structure, manually lifting the vibrator or pulling it to a new location results in undue stress on the back of the workers (see Fig. $1 \mathrm{a}-\mathrm{d}$ ). By using cordless and light vibrators one can minimize the stress on the workers' backs, however, these vibrators have less effect and to compensate for this they have to be used for longer.

It is recommended that further action be taken to mitigate the exposure to musculoskeletal risk factors within each of the identified concrete casting tasks. The implementation of ergonomic interventions has been found to reduce the amount and severity of musculoskeletal disorders within the working population in various industries (Hendrick 2008). It is recommended that ergonomic interventions may be implemented in the concrete casting process of bridge construction projects in Sweden to minimize hazards in the identified job tasks. 


\section{References}

Adams, S. 1989. Practical buildability. London: Butterwoths. $128 \mathrm{p}$.

Amprazis, J.; Christmansson, M.; Falck, A.-C. 2002. ErgoSAM - a production technology method for early identification of load ergonomics problems, in Nordic Ergonomics Society (NES) Conference, Norrköping, Sweden, 2002. $4 \mathrm{p}$.

Arbetsmiljöverket [Swedish Work Environment Authority]. 2005. Arbetsmiljöverkets Författningssamling [Work Environment Authority constitution], Buller, Arbetsmiljöverkets föreskrifter om buller samt allmänna råd om tillämpningen av föreskrifterna [Noise, Work Environment Authority's regulations on noise as well as the general application of regulations], Stockholm, Sweden. 32 p.

Brite Euram. 2000. Final Report of task 8.5, Brite Euram Proposal no. BE96-3801, Task name: Environment and Ergonomics. Final Report. 31 p.

Brown, R.; Li, G. 2003. The development of action levels for the Quick Exposure Check (QEC) system, in P. T. McCabe (Ed.). Contemporary Ergonomics. London: Taylor \& Francis, 41-46.

Cussigh, F. 2007. SCC in practice: opportunities and bottlenecks, in The 5th International RILEM Symposium on SelfCompacting Concrete, 3-5 September, 2007, Ghent, 21-27.

David, G.; Woods, V.; Li, G.; Buckle, P. 2008. The development of the Quick Exposure Check (QEC) for assessing exposure to risk factors for work-related musculoskeletal disorders, Applied Ergonomics 39(1): 57-69. http://dx.doi.org/10.1016/j.apergo.2007.03.002

David, G. C. 2005. Ergonomic methods for assessing exposure to risk factors for work-related musculoskeletal disorders, Occupational Medicine 55: 190-199. http://dx.doi.org/10.1093/occmed/kqi082

De Schutter, G.; Barthos, P. J. M.; Domone, P.; Gibbs, J. 2008. Self-Compacting Concrete. Dunbeath, Caithness, Scotland, UK: Whittles Publishing. 288 p.

Drugă, C.; Barbu, D.; Lache, S. 2007. Correlation between noise, vibrations and people's health, in Annals of the Oradea University, Fascicle of Management and Technological Engineering 6(16): 174-179.

Emborg, M.; Simonsson, P.; Carlswärd, J.; Nilsson, M. 2007. Industrial casting of bridges combining new production methods and materials, like a robust SCC, utilizing lean construction principles, in The 5th International RILEM Symposium on Self-Compacting Concrete, 3-5 September, 2007, Ghent, 485-490.

Emborg, M.; Jonasson, J.-E.; Nilsson, M.; Utsi, S.; Simonsson, P. 2005. Designing robust SCC for industrial construction with cast in place concrete, in The 4th International RILEM Symposium on Self-Compacting Concrete, 30 October-2 November, 2005, Chicago, USA, 1251-1257.

European Agency for Safety and Health at Work. 2004. Bilbao Declaration - Building in safety, European construction safety summit, 22 November, 2004 [cited 21 June 2010]. Available from Internet: $<$ http://agency.osha.eu.int/publications/other/20041122/en/index 1.htm>.

European Agency for Safety and Health at Work. 2010. Workrelated musculoskeletal disorders in the EU - Facts and figures. European Risk Observatory Report. 179 p.

Flanagan, F.; Jewell, C.; Larsson, B.; Sfeir, C. 2001. Vision 2020: Building Sweden's Future. Technical Report, Department of Building Economics and Management: Chalmers University of Technology, Sweden. $111 \mathrm{p}$.
Fernández-Muñiz, B.; Montes-Peón, J. M.; Vázquez-Ordás, C. J. 2009. Relation between occupational safety management and firm performance, Safety Science 47(7): 980-991. http://dx.doi.org/10.1016/j.ssci.2008.10.022

Fung, I. W. H.; Tam, V. W.-Y.; Tam, C. M.; Wang, K. 2008. Frequency and continuity of work-related musculoskeletal symptoms for construction workers, Journal of Civil Engineering and Management 14(3): 183-187. http://dx.doi.org/10.3846/1392-3730.2008.14.15

Gambatese, J. A.; Rejandran, S. 2006. Building toward sustainable safety and health, in ASSE Professional Development Conference and Exposition, 11-14 June, 2006, Seattle, Washington, USA. $13 \mathrm{p}$.

Gervais, M. 2003. Good management practice as a means of preventing back disorders in the construction sector, Safety Science 41(1): 77-88. http://dx.doi.org/10.1016/S09257535(01)00070-4

Goldsheyder, D.; Weiner, S. S.; Nordin, M.; Hiebert, R. 2004. Musculoskeletal symptom survey among cement and concrete workers, Work 23(2): 111-121.

Halliday, S. 2008. Sustainable Construction. ButterworthHeinemann Publications. 395 p.

Hendrick, H. W. 2008. Applying ergonomics to systems: Some documented "lessons learned", Applied Ergonomics 39(4): 418-426.

http://dx.doi.org/10.1016/j.apergo.2008.02.006

Heinrich, H. W. 1931. Industrial accident prevention: A scientific approach. New York: McGraw-Hill Book Company. $366 \mathrm{p}$.

Hess, J. A.; Hecker, S.; Weinstein, M.; Lunger, M. 2004. A participatory ergonomics intervention to reduce risk factors for low-back disorders in concrete laborers, Applied Ergonomics 35(5): 427-441. http://dx.doi.org/10.1016/j.apergo.2004.04.003

International Standard ISO 1999:1990 The minimum health and safety requirements regarding the exposure of workers to the risks arising from physical agents (noise). EU Directive 2003/10/EC of the European Parliament and the Council, 6 February, 2003.

Jergeas, G.; Van der Put, J. 2001. Benefits of constructability on construction projects, Journal of Construction Engineering and Management ASCE 127(4): 281-290. http://dx.doi.org/10.1061/(ASCE)0733-9364(2001)127: 4(281)

Kemmlert, K. 1995. A method assigned for the identification of ergonomic hazards - PLIBEL, Applied Ergonomics 26(3): 199-211. http://dx.doi.org/10.1016/0003-6870(95)00022-5

Kemmlert, K. 2006. PLIBEL - A method Assigned for Identification of Ergonomic Hazards, in W. S. Marras and W. Karwowski (Eds.). The Occupational Ergonomics Handbook: Fundamentals and Assessment Tools for Occupational Ergonomics. $2^{\text {nd }}$ ed. Taylor \& Francis Group, 3.1-3.7.

Kyo-Jin, Y.; Langford, D. 2006. Scheduling-based risk estimation and safety planning for construction projects, Journal of Construction Engineering and Management ASCE 132(6): 626-635. http://dx.doi.org/10.1061/(ASCE)07339364(2006)132:6(626)

Larcher, P.; Sohail, M. 1999. WELL Study: Review of Safety in Construction and Operation for the WS\&S Sector: Part I. Task No 166. London School of Hygiene \& Tropical Medicine and WEDC, Loughborough University. 16 p.

Li, G.; Buckle, P. 1997. The development of a practical method for the exposure assessment of risks to work-related mus- 
culoskeletal disorders. General report to the HSE (Contract No. R3408). Robens Centre for Health Ergonomics, European Institute of Health and Medical Sciences, University of Surrey. $82 \mathrm{p}$.

Li, G.; Buckle, P. 1999. Current techniques for assessing physical exposure to work related musculoskeletal risks with emphasis on posture-based methods, Ergonomics 42(5): 674-695. http://dx.doi.org/10.1080/001401399185388

Lundholm, L.; Swartz, H. 2006. Musculoskeletal ergonomics in the construction industry. Facts \& figures in brief. No. 5.2006. Swedish Work Environment Authority. [cited 2 June 2011]. Available from Internet: $<$ http://www.av. se/dokument/inenglish/statistics/Sf_2006_05_en.pdf $>$.

Lundholm, L.; Swartz, H.; Weiner, J. 2007. Belastningsergonomi $i$ byggverksamhet. Arbetsmiljöverket, Korta sifferfakta [Musculoskeletal Ergonomics in construction work. Work Environment Authority. Short facts]. No 13.2007.

Nielsen, C. 2006. New results regarding SCC and working environment, The Nordic SCC Network Workshop, SCC, Vision and Reality, 19 June, 2006, Copenhagen, Danish Technological University. 5 p.

Okamura, H.; Ouchi, M. 2003. Self-compacting concrete, Journal of Advanced Concrete Technology 1(1): 5-15. http://dx.doi.org/10.3151/jact.1.5

Ray, S. S. 1996. CIRIA - Bridge design for improved buildability. Construction Industry Research and Information Association, Report No $155.162 \mathrm{p}$.

Rose, L. 2001. Models and Methods for Analysis and Improvement of Physical Work Environments. PhD thesis. Chalmers University of Technology, Department of product and production development, Division of Human Factors.

Rose, L.; Orrenius, U. 2006. Beräkning av arbetsmiljöns ekonomiska effekter på företag och organisationer, En översikt av ett urval modeller och metoder [Calculation of work environment effects on companies and organisations. An overview of a choice of models and methods]. Technical Report. Working Life Institute, Sweden. 58 p.
Rwamamara, R. 2007. Planning the healthy construction workplace through risk assessment and design methods. $\mathrm{PhD}$ thesis. Luleå: Luleå tekniska universitet [Luleå University of Technology].

Samuelsson, B. 2010. Arbetsskador inom byggindustrin 2009. Bygg- och anläggning - privat sektor [Work-related injuries in the construction industry in 2009. Building and Civil Engineering. Private Sector]. BCA 2010:1. Stockholm: Construction Work Environment Council. 35 p.

Samuelsson, B.; Lundholm, L. 2006. Arbetsskador inom byggindustrin 2005. Bygg-och anläggning. Privat sektor. [Work-related injuries in the construction industry in 2005. Building and Civil Engineering. Private Sector]. BCA 2006:2. Stockholm: Construction Work Environment Council. $38 \mathrm{p}$.

Samuelsson, B. 2008. Arbetsskador i byggverksamhet 2007. Privat och offentlig verksamhet [Work-related injuries in the construction work in 2007. Private and Public Sector]. BCA 2008:2. Stockholm: Construction Work Environment Council. $70 \mathrm{p}$.

Shah, S. P.; Ferron, R. P.; Ferrara, L.; Tregger, N.; Kwon, S. 2007. Research on SCC: some emerging themes, in The 5th International RILEM Symposium on Self-Compacting Concrete, 3-5 September, 2007, Ghent, 3-14.

Swedish Social Insurance Agency. 2004. How much do diseases cost for women and men? Sick leave compensations distributed according to gender and sick-leave diagnosis. Stockholm, Swede. Report 2004:5.

The Council of European Communities. 2003. Directive $2003 / 10 /$ ec of the European parliament and of the council, Official Journal of the European Union, L42/38 - L42/44.

Wong, F.; Lam, T. I.; Shen, L. Y. 2004. A dynamic design management system for improving buildability of construction, in Proc. of the 20th ARCOM conference, 1-3 September, 2004, Heriot Watt University, Association of Researchers in Construction Management, Vol. 1, 185194.

Romuald RWAMAMARA. Senior Researcher, Division of Structural and Construction Engineering, Luleå University of Technology, Sweden.

Peter SIMONSSON. Senior Researcher, Division of Structural and Construction Engineering, Luleå University of Technology, Sweden. 